\title{
Pop Life: The Popular Music Biopic - Introduction
}

\author{
Matthew Bannister
}

\author{
Waikato Institute of Technology, Hamilton, Aotearoa/New Zealand \\ matthew.bannister@wintec.ac.nz
}

The relation of sound and image and, more specifically, music and film is a tricky issue. Normative histories of film prioritize image over sound, and music studies sometimes simply reverse the hierarchy. Whereas the visual is often described as hegemonic in Western culture, sound is regarded as subversive: the listener's immersion as opposed to the one-directional visual engagement of the onlooker (Dyson 2009). The music biopic, a film that documents (and mythologizes) musicians' life stories, provides an opportunity to ponder these issues and others, including relations between different types of popular music, music film, and the kinds of identities associated with them.

Jolson Sings Again (1949) marks an important point in the evolution of the music biopic - important, because Al Jolson helped establish sound in cinema via the introduction of the "talkie" in The Jazz Singer (1927), which is, formally if not literally, a musical biopic (Gabbard 1996), while silent film was usually accompanied by music. These two points illustrate the intimate relation of music and film, and, moreover, the centrality of the biopic genre to Hollywood film, contradicting routine critical dismissals by authors such as Bingham (2010), or Altman (1989):

Jolson Sings Again is ... a record of the making of Columbia's earlier film The Jolson
Story (1946). Instead of hiding the fact that Jolson didn't play himself in the earlier
film, Jolson Sings Again actually shows Jolson recording his songs while the actor
who is to play him on the screen mouths the words. While this scene thoroughly
lays bare the biopic's devices, it also lays the groundwork for a complete
reinstatement of the genre. When "Jolson" watches his stand-in mimic him, he is
thoroughly touched by the fidelity of the actor's performance... Jolson Sings Again
reveals the technology behind the biopics - Hollywood's backstage arena - only in
order to "prove" that even the great Jolson is impressed with the accuracy of

IASPM@Journal vol.7 no.1 (2017)

Journal of the International Association for the Study of Popular Music

ISSN 2079-3871 I DOI 10.5429/2079-3871(2017)v7i1.2en I www.iaspmjournal.net 
Hollywood's portrait... The film foregrounds technology only in order to hide it more fully. (Altman 1989: 253-254)

Jolson Sings Again (the title referring not only to its sequel status but also to the remediation of his performances on film) was a turning point in the history of the musical. By drawing attention to the process of its own production (through dub-ling: the doubling of performers playing the same role and the foregrounded dubbing as one performer mimes to another's voice), the film addressed contemporary concerns that musicals were corny, effectively giving the genre a second wind, which lasted until the late 1960s when the realism of New Hollywood, combined with the rise of the rock youth counterculture, led to the popular music biopic superseding the musical from the late 70s on (Bingham 2010).

A good deal was lost in this transition - the biopic was based on an individual, while the musical typically featured a dual focus narrative, with paired scenes playing around two characters (usually a romantic couple): "each [narrative] segment ... understood not in terms of the segments to which it is causally related but by comparison to the segment which it parallels" (Altman 1989: 22). By largely eschewing the dual focus of the musical for the familiar heroic journey, the music biopic risked becoming predictable, even monomaniacal in structure, and the possibility of equal time on-screen for men and women (albeit in a heterosexual romance context) was lost. Indeed, the plot of The Jolson Storyturns on Jolson's divorce, establishing the familiar, "realistic" dynamic of masculine public life winning out over the demands of female domesticity. Also at risk was the musical's utopian potential, while in its place a sometimes monotonous realism prevailed, interspersed with sporadic conflicts between alienated romantic artists and the forces of social conformity (Dyer 1992). But this realism was paradoxically much more acceptable to the 1960 s youth counterculture, which demanded an end to Hollywood fabrication, and preferred "cinema direct" and documentary to fiction (Neaverson 1997).

Both the Hollywood musical and the counterculture appropriated continuously from African-American culture, its music and dances re-performed by white actors and singers such as Al Jolson; acts of racial "doubling" such as blackface, which parallel and intersect with the dub-ling discussed above in relation to the sound film. In Jolson Sings Again, "White Jolson" watches the actor playing him performing at the film shoot - in blackface. Although initially anxious, he eventually approves the performance, legitimizing not only Hollywood's "fakery" but also its (and Jolson's) appropriation of black American culture - indeed he becomes over-enthusiastic, applauding himself wildly in a way that interferes with the film technicians. This represents the racist fantasy of "excess" in African-American culture, its jouissance, which is at once sought-after (musical exuberance and spontaneity, joy) but is simultaneously tamed by a white Hollywood establishment. Notably, when Jolson nervously attends the premiere of his "own" film (which is of course the A/Jolson Story, and by allusion, also The Jazz Singer), its initial scenes are all in blackface, but later scenes are without make-up, and thereby rendered "white". This narrative progression parallels Jolson's self-acceptance - as the 
narrative becomes "whiter", he relaxes. Appropriation of African-American culture also links to authenticity - it is the "source" of musical and performative energy in the musical film, but not one that could be directly acknowledged in post-war Hollywood. This dynamic, or more broadly, the search for "authenticity", also informs the later rock music biopic.

Authenticity relates to both popular music and the biopic form in different and sometimes conflicting ways. In telling a story about a living person, a biopic is supposed to display verisimilitude, which could be in setting, time and place, historical accuracy, and/or in an interpretation of the facts of a musician's life. Immediately, however, the choice of entertainer as subject complicates matters, as their performances intersect with the film-as-performance, and their life story intersects with the requirements of Hollywood narrative and pre-existing examples of the genre, as in the Jolson films. "Let's agree on one thing at the start, boys. I don't think anybody cares about the facts of my life, about dates and places. I'Il give you a mess of them, you juggle them any way you like." (Larry Parks as Al Jolson, talking to screenwriters in Jolson Sings Again. Quoted in Custen 1993: 110). What really matters to Jolson (and by implication, the audience) is the music, or more accurately, the use of his singing voice in the film. Authenticity is as much a matter of aesthetic preference as historical accuracy. With that in mind, I turn to the essays in this issue.

Jonathan Stewart, Benjamin Halligan and Liam Maloy, who were involved in the making of Control and Telstar, two recent UK music biopics about Joy Division and Joe Meek, interview key players in those films about maintaining verisimilitude in the production process. Along with concern for accuracy, there was an equal concern with being true to the "spirit" of the music and its time and place, which chiefly takes the form of being true to contemporary styles of mediation. Contro/s monochrome aesthetic relates to Anton Corbijn's direction - his black and white stills established Joy Division's image of glamorous privation in the late 1970s UK music press. Likewise, the makers of Telstar based its aesthetic on early 1960s UK film, from Cliff Richard to kitchen sink dramas. Financial restrictions enhance verisimilitude because the music was also made on a low budget (for example, Meek produced hits in his flat; Joy Division incarnated a working class indie aesthetic) so the mode of film production seems true to the music artists ${ }^{1}$ Similarly, casting unknowns as leads plays into an alternative ethos - could one really countenance Jude Law playing Ian Curtis? Custen, however, notes the traditional Hollywood thinking that a biopic was a way to break in a new star, as "an established personality... is never accepted as readily" (1993: 196). Additional authenticity is adduced in the case of Control by the use of Deborah Curtis's (Ian's widow) autobiography for the film. In the final analysis, accuracy is ultimately about the intertextual correspondence of the filmic text. 
Most early Hollywood entertainer biopics took a casual attitude to facts, and their subjects were often happy to go along with this - Cole Porter's main concern in Night and Day (1946) was how many of his songs were used in the film, and neither he nor the film producers wished to put his homosexuality on public display (Custen 1993). Telstar, in contrast, can include aspects of Meek's gay life, partly because he is dead, and partly because public attitudes about homosexuality have changed, although not necessarily in Hollywood, as we find in the article by Stewart, Halligan and Maloy. At the same time, Telstar is marked by a playful aesthetic - shooting stars magically appear when characters get ideas - original 1960s artists played many of the older characters, making for a cheeky self-referentiality often lacking in the classic biopic. A camp disregard for the facts and a gay male gaze marked a number of music biopic/musicals made in the 1960s and early 1970s, from Funny Gir/(1968) to Ken Russell's composer biopics. However, these films were anathema to the emergent rock discourse (Keightley 2001).

Concerns about accuracy in the popular music biopic are a comparatively recent phenomenon, driven by the 1960 s youth counterculture's conviction that rock music was art, interference from the film/entertainment industry was necessarily suspect, and documentary preferred for representations of rock culture (Keightley 2001; Neaverson 1997). And typically documentaries focused on live performance. The concert film Woodstock(1970), Gimme Shelter(1970), The Concert for Bangladesh(1972), The Song Remains the Same (1976) - highlighted the rock ideology of "liveness" (Auslander 2008). In doing this, it also seems to solve a key problem of the artist biopic - how to show the creative process on film, although equating creativity with live performance risks reifying the rock ideology of "spontaneous liveness" as the norm for popular music production. Maurizio Corbella's essay in this issue (pages 29-53) focuses on the remediation of historic live performances in The Buddy Holly Story (1978), Johnny Cash biopic Walk the Line (2005) and James Brown biopic Get On Up (2014). In each case he focuses on a mediation of a historic live performance - the set-list of Buddy Holly's last gig, the 1968 Johnny Cash live LP At Folsom Prison, and the 1968 live telecast of Brown's concert the day after Martin Luther King's assassination. He concludes that, "media documents of a past event owe much of their performative impact to the fact that they were contingent to the historical moment of their production" (p. 48) That is, they are not true records, but texts, the meaning of which only emerges in time, or in particular times and places - the past is meaningless unless it can be related to the present moment of production. This is more complex than saying that truth has been manipulated to fit dominant narratives or discourses (although that is one possibility), rather it points to how music films continue to affect audiences and create new fans and possibilities. To take a personal example, I was not a Johnny Cash fan until I saw Walk the Line (2005) but if I had been, the inaccuracies in the film might have spoiled my enjoyment. Affect and knowledge are not always commensurable.

So far we have discussed popular music biopics in terms of a dominant discourse of Anglophone media culture (while acknowledging economic differences between, say, 
indie UK and Hollywood productions). But popular music and film is a global phenomenon, and local practices around popular music and its representation may diverge sharply. Ewa Mazierska (pages 54-68) argues that in 1980s Poland, a crumbling Communist regime, popular music artists (such as Maanam) and filmmakers related to media and each other in distinctive ways: "Polish filmmakers neglected ... the principal aim of western biopics, namely telling the truth about their characters" (p.55). A Communist de-emphasis on individual stars, participation in a system in which cultural production was transitioning from state control to free market capitalism, and a distinctive strain of nationalist romanticism deriving from Poland's long history of occupation, all combine to produce films that play on the boundaries of the music biopic genre.

Environmentalism presents another kind of challenge to conventional definitions of music and film. The reality of climate change is so overwhelming that it is tempting either to deny it or to wonder how popular music, and films about popular music stars, could possibly be read in such a light. The growth of ecomusicology suggests otherwise (Allen and Dawe 2016; Ingram 2010). Bridget Sutherland and Paul Judge (pages 69-85) interpret iconic films about American music icons - Elvis Presley and Jim Morrison - in the light of the Anthropocene. On one level, they simply equate the doomed romantic artist striving "against nature" with the fate of the planet in general. Yet, on another level, the essay reads the respective protagonists as inchoate environmental activists, revealing in Morrison's case a hidden history of ecological concern. Elvis (1979), the film, constructs its protagonist as a force of nature who withers once separated from his "roots": "nature as a source of ethical, and therefore aesthetic value" (Ingram 2010: 44), a familiar but influential narrative. E/vis set the mould for later neo-classical biopics such as Walk the Line. Elvis symbolized America, and America symbolizes the western dream of progress, so the fall of one is the fall of the other. Morrison functioned similarly in relation to the US counterculture: as a poet, artist, sex symbol, alcoholic, shaman, wife beater, he summed up its contradictions (Marcus 1991).

Another distinctive response to the popular music biopic is the work of Todd Haynes, whose successive forays in this genre - Superstar: The Karen Carpenter Story (1988) to Velvet Goldmine (1998) to I'm Not There (2007) - have been described as "blatant in their intention to refract and shatter traditional conceptions of unitary subjectivity, linear temporality and historical truth" (Darby 2013: 388). In all these films, the biographical subject is absent or open to question - Karen Carpenter is a Barbie doll, David Bowie is present by inference as a bisexual Citizen Kane-like enigma, and Bob Dylan is played by a gallery of six actors and seven characters. Marcus O'Dair considers the last of these films, I'm Not There, arguing that despite its title and premise, Dylan is indeed "there" in the text, not as a unifying subject, but as "a series of specific and complex operations", as in Foucault's notion of author-discourse: discourses create authors (not the other way 
round) through a process of author-ization. An "author" identity is created through participating in systems of authority and legitimation (Foucault 1984: 113). Dylan author-izes the film (and it is an authorized bio-pic), also in the postmodern sense that the author's name gathers and organizes different texts and voices - like Walt Disney or Andy Warhol - a trademark, or brand. Not just any brand (one is tempted to take O'Dair's argument further and posit Dylan as one of the "founders of [rock] discursivity"): Dylan sets the template for the modern rock "auteur" (Foucault 1984: 114; Marshall 2007). His continual metamorphoses and refusal of closure are echoed in Haynes' film. But the final point is that Dylan is present in the film via his verbal wit and music, notwithstanding the lack of a character by his name. And this returns us to our starting point - ultimately the sound of film means just as much as its images (Goodwin 1992). The multiplicity of voices in Haynes' work opens up the biopic once again to the richness of musical tradition, and the possibility of models of popular music stardom not predicated on alienated romantic white male heroes.

With this diverse set of articles, I hope that this issue will provide some guidance to readers negotiating the range of biographical, filmic texts now available in the field of popular music.

\section{Endnotes}

${ }^{1}$ However, the indie, low-budget discourse was often contradicted in practice - Martin Hannett's preduction and Peter Saville's record sleeves, like Corbijn's photographs, aestheticised and heightened the band's austere sound and image.

\section{References}

\section{Bibliography}

Allen, A. and K. Dawe. 2016. Current Directions in Ecomusicology: Music, Culture, Nature. London and New York: Routledge.

Auslander, P. 2008. Liveness: Performance in a Mediatized Culture. London and New York: Routledge.

Altman, R. 1989. The American Film Musical. London: British Film Institute, 1989.

Bingham, D. 2010. Whose Lives Are They Anyway? The Biopic as Contemporary Film Genre. New Brunswick, New Jersey: Rutgers University Press.

Custen, J. F. 1993. Bio/Pics: How Hollywood Constructed Public History. New Brunswick, NJ: Rutgers University Press.

Darby, H. 2013. "I'm Glad I'm Not Me: Subjective Dissolution, Schizoanalysis and Post-structuralist Ethics in the Films of Todd Haynes", Film-Philosophy 17 (1): 330347. http://www.film-philosophy.com/index.php/f-p/issue/view/87.

Dyer, R. 1992. Only Entertainment. New York: Routledge. 
Dyson, F. 2009. Sounding New Media: Immersion and Embodiment in the Arts and Culture. Berkeley: University of California Press.

Foucault, M. 1984. What is an Author? In P. Rabinow Ed. The Foucault Reader: an Introduction to Foucault's Thought. 101-120.

Gabbard, K. 1996. Jammin' at the Margins: Jazz and the American Cinema. Chicago: University of Chicago Press.

Goodwin, A. 1992. Dancing in the Distraction Factory. Minneapolis: University of Minnesota Press.

Ingram, D. 2010. Jukebox in the Garden. Amsterdam; New York: Editions Rodopi.

Keightley, K. 2001. Reconsidering Rock. In Cambridge Companion to Pop and Rock, edited by S. Frith, W. Straw, J. Cambridge: Cambridge University Press: 109-142.

Marcus, G. 1991. Dead Elvis: A Chronicle of a Cultural Obsession. Cambridge, MA: Harvard University Press.

Marshall, L. 2007. Bob Dylan: The Never Ending Star. Cambridge, UK: Polity.

Neaverson, B. 1997. The Beatles Movies. New York: Cassell.

\section{Videography}

Control. 2007. Dir. Anton Corbijn, Momentum Pictures; The Weinstein Company. Elvis. 1979. Dir. John Carpenter, Dick Clark Productions.

Funny Girl. 1968. Dir. William Wyler. United States: Columbia Pictures; Rastar Pictures.

Get On Up. 2014. Dir. Tate Taylor. Imagine Entertainments/Jagged Films/Wyolah Films.

Gimme Shelter. 1970. Dir. Albert and David Maysles. Penforta; Maysles Productions. I'm Not There. 2007. Dir. Todd Haynes. The Weinstein Company.

Jolson Sings Again. 1949. Dir. Henry Levin. Sidney Buchman Enterprises; Columbia

Pictures Corporation.

Night and Day. 1946. Dir. Michael Curtiz. Warner Bros.

Superstar: The Karen Carpenter Story. 1988. Dir. Todd Haynes. Iced Tea Productions. Telstar: The Joe Meek Story. 2008. Dir. Nick Moran, Aspiration Films / G2 Pictures. The Buddy Holly Story. 1978. Dir. Steve Rash. Innovisions/ECA.

The Concert for Bangladesh. (1972). Dir. Saul Swimmer. Apple Corps, Twentieth

Century Fox Film Corporation, US Committee for UNICEF.

The Jazz Singer. 1927. Dir. Alan Crosland. Warner Bros.

The Jolson Story. 1946. Dir. Alfred Green. Columbia Pictures Corporation.

The Song Remains the Same. 1976. Dir. Peter Clifton, Joe Massot. Swan Song. Velvet Goldmine. 1998. Dir. Todd Haynes. Channel 4 Films, Goldwyn Films, Killer

Films, Miramax, Newmarket Capital Group, Single Cell Pictures, Zenith

Entertainment. 
Walk the Line. 2005. Dir. James Mangold. Fox 2000 Pictures et al. Woodstock. 1970. Dir. Michael Wadleigh, Wadleigh-Maurice.

Discography

Johnny Cash, 1968. Live At Folsom Prison. Columbia, May, US. 